\title{
Praxis and language: Teaching newly arrived migrant children to "live well in a world worth living in"
}

\section{MERVI KAUKKO AND JANE WILKINSON Monash University}

Abstract: This article continues the well-established discussion of the ethics of TESOL by adopting a praxis perspective that views TESOL as holistic, ethical and moral task, rather than a technical task of delivering learning outcomes in a new language. This article is informed by the authors' empirical research in Finnish preparatory classes, and in intensive English language schools in Australia, including interviews with teachers, students and educational leaders. Drawing on literature and this research we consider how English as an Additional Language or Dialect (EALD) and Finnish as a Second Language (F2) teaching can promote "a good life" for the individual learner and human kind.

Keywords: praxis, ethics, language schools, TESOL, Finland, Australia, newly arrived students

\section{Introduction}

Education is fundamentally about our futures as societies, nations and a world. It is also about the futures of individuals who live in this world. Praxis-literature (for example, Kemmis \& Smith, 2008; Kemmis et al., 2014) conceptualises this as the double purpose of education: "preparing people to live well in a world worth living in" (Kemmis et al., 2014, p. 27). As such, the double purpose of education includes a view about how people should live in the world, and about the kind of world they should establish (Kemmis et al., 2014, p. 27).

This article takes a praxis approach to consider the double purpose of English as an Additional Language or Dialect (EALD) and Finnish as a Second Language (F2) education: What is the "good life" we want individual students to achieve through this education, and what is the "world worth living in" we hope to see in our societies as a result of their learning? Our article does not claim to offer answers to these large and contested questions but 
instead, by drawing on research from two geographical contexts, Finland and Australia, considers teaching the dominant language (Finnish in Finland and English in Australia) for newly arrived migrant children and youth as ethical praxis. Thus, this article continues the well-established discussion (Crookes, 2009; Dufon, 1993; Williams, 1992) of the ethics of TESOL, which we suggest has so far paid little attention to the praxis perspective. In line with the praxis approach, we frame EALD/F2 teaching as a holistic, ethical and moral task, rather than a technical task of delivering the learning outcomes in the new language.

This article is conceptual in nature, but it is informed by the authors' empirical research in Finnish preparatory classes ${ }^{1}$, and in intensive English language schools in Australia, including interviews with teachers, EALD/F2 students and educational leaders. We start the article by briefly discussing teaching language to newly arrived migrant students as praxis. In the second part of the article, we draw on literature, current policies and our empirical research, and give a short overview of language education for newly arrived school-aged students in the two countries. In the end we discuss, in light of these documents and research evidence, the ethical praxis in EALD/F2 teaching.

\section{Praxis in EALD/F2 education}

In the last several decades, there have been countless interpretations of (educational) praxis (Freire, 2000; Habermas, 1973; hooks, 2007; Kemmis \& Smith, 2008; Mattsson, Johansson \& Sandström, 2008). Although these interpretations vary considerably, depending on their social and historical contexts, most have roots in either Aristotelian or Marxist views. Based on the Aristotelian view, praxis is a "right conduct", involving self-aware, wise and prudent actions, as distinct from solely technical or theoretical actions (Kemmis, 2009). Aristotelian praxis aims for the good of those involved, as well as good for human kind. It is oriented and informed by traditions in the field (Kemmis \& Smith, 2008, p. 4) and, as such, it reflects the interpretation of "good" as the time

\footnotetext{
${ }^{(1)}$ Preparatory education is a targeted program for recently arrived migrant students, aiming at providing them with sufficient level of Finnish or Swedish language and other necessary skills while studying in small groups before entering the mainstream education.
} 
and place in which it happens. Kemmis and Smith (2008) among others note that in Aristotelian ethics, human beings are inclined to "do good" because of their natural capacity for reason; praxis is the rational action of an individual who is trying to reach his or her own happiness. This kind of praxis only requires the "right" interpretation of what already is, and a willingness to act towards what ought to be. Thus, assuming individuals are inclined to do good, their search for their own happiness results in the betterment of life for human kind (Groundwater-Smith et al., 2013). In contrast to Aristotles's view on praxis, Marx (Marx \& Engels, 1845/1998) and many writers after him (such as Freire, 2000), used praxis for social critique. In Marx's view, praxis is human made "history-making action": any action with moral, social and political consequences, good or bad, for those who are involved in and affected by it (Kemmis \& Smith, 2008, p. 4). Also this latter view emphasises the "happeningness" of praxis: it is something that actually happens, and it cannot be taken away from its context.

Praxis research aims to make contributions to both educational theory and practice. As Carr and Kemmis (1986) argued more than three decades ago, education practitioners (such as teachers) can transform their practice, their understandings of practice, and the conditions under which their practice is carried out by engaging in critical and continuous reflection on their work. Ponte and Smit (2016), Groundwater-Smith et al. (2013) and Doecke, Kostogriz and Illesca (2010) note that, on the one hand, the practical implications of praxis can be explored by looking at practitioners' (usually teachers') capabilities of acting ethically, autonomously and rationally, and as their capacity to reflect on their practice both pragmatically and ideologically (see also Carr \& Kemmis, 1986). This view on praxis emphasises the lifeworld of individuals (Habermas, 1989), that is, the everyday world of informally, culturally grounded understandings that we share with others (Habermas, 1984). Alternatively, a system theory oriented viewpoint is to look at the cultural, social and political contexts in which practitioners act, including the structural and ideological constraints and possibilities that influence their work (Doecke et al., 2010, referring to Lukacs, 1971). In this article, we consider praxis within the framework of practice theories (Kemmis et al., 2014), aiming to overcome this duality of lifeworlds and systems. 
Although educational praxis with newly arrived students has not yet been explored sufficiently, a recent book Professional development: Education for all as praxis by Wilkinson, Bristol and Ponte (2016) is a good exception. The authors argue that praxis with diverse groups of learners, such as groups of newly arrived migrant students, requires teachers to extend their critical reflection beyond their immediate teaching practice and consider what is good for individual learners now and in the future (regardless of where they will be) and what kind of practices resonate with the lifeworlds of the child (regardless of how distant they are from the world of the teacher). This is praxis which responds to the particular circumstances surrounding "uncertain practical questions" (Reid, 1978, as referred to in Kemmis et al., 2014, p. 26). These are questions which the teacher or the learner may not anticipate and which can only be evaluated based on their consequences (Kemmis et al., 2014). This view of praxis, as defined in Aristotelian and post-Marxist traditions, prompts teachers to think about the meaning of their actions towards the child and the world, with all its uncertainties. It requires more than just the individual teacher's intention to "do good"; it takes into consideration educational actions that are social, sometimes unintended, or at times have hidden manipulative consequences for equity and justice (Groundwater-Smith, 2013). In other words, it is ethical praxis in which teachers "take into account all the circumstances and exigencies that confront them at a particular moment and then, taking the broadest view they can of what it is best to do, they act" (Kemmis \& Smith, 2008, p. 4).

This of course is easier said than done. For EALD/F2 teachers (or in fact for all teachers) this requires considering not only the circumstances and conditions related to language but also the conditions of school and society at large. For example, when working with newly arrived migrants, teachers may need to take a stance against injustice in the classroom or society and model respectful interaction with different cultures. This kind of educational work is praxis which can be judged not only in terms of knowledge transfer, but also in terms of fundamental ideas of what is just and right (Groundwater-Smith et al., 2013, p. 4). Constant interpretations of what is just and ethical, and how to interpret the changing situations in the most appropriate way are inseparable from this work. It is in line with the argument proposed by Williams (1992, p. 5) in this journal: "TESOL practitioners must be politically active; they must understand 
linguistic pluralism and its effects throughout society, and act accordingly."

We do not suggest that this would be unique for EALD/F2 teachers, or that they would be more attuned to injustices than other teachers. We do suggest that working with students with very diverse backgrounds, as EALD/F2 teachers often do, prompts teachers to consider ethical questions broadly. However, the same ethical questions are relevant for all teachers: How do teachers come to know what is appropriate? Is it appropriate in this particular situation or across any situations or sites of practice? How to define the best interest of the student?

Next, we discuss language and the double purpose of education, aiming for a "good life" for the individual learner and society.

\section{A "good life" and language}

It is easy to justify the need to learn the language of a new country for the individual learner. A good life, however it is defined, is supported by functional communication in the language of the society. Yet, whether or not teaching the dominant language automatically supports the "good life" is a contested issue. Australian scholar Alan Williams noted, as early as 1992, that although language teachers mostly mean well, their practices can have several unintended side effects. Reviewing literature on language teaching (Alisaari, Heikkola, Commins \& Acquah, in press; Peguero \& Bondy, 2011; Suarez-Orozco, Pimentel \& Martin, 2009; Zilliacus, Holm \& Sahlström, 2017), we can see that it is still the case.

For example, it might be assumed that for newly arrived migrant children, learning the basics of effective communication is what is needed the most (see, for example, Usman, 2012). The justification may be found in a view that only language can help students to get ready for their forthcoming "real education" in a mainstream classroom, and life outside of school. Alternatively, it may be considered that social inclusion is of paramount importance, and for this reason, students should most of all learn the values and norms of the new society (Correa-Velez et al., 2010). This may be justified by a view that the purpose of education is larger than language: it is to prepare students to become members of their new societies. A third approach puts students' overall wellbeing as a priority, after which language learning and adaptation may follow. This view, common 
particularly when working with refugee and asylum-seeking students, may be justified by an assumption that because of their difficult experiences, students need to "recover" and overcome possible trauma before learning can take place (Graham, Minhas \& Paxton, 2016).

The views so far discussed are not the only possible interpretations of a newly arrived child's best interest, and are by no means mutually exclusive. Yet in practice, the ways in which the teacher balances their importance inevitably influences what she or he does with students (van Kan, Ponte \& Verloop, 2013). Emphasising the functional role of language and the utility of effective communication in the dominant language runs a risk of unintentionally overlooking or simply misunderstanding other issues which are significant for learning. Some teachers fail to value and utilise the existing linguistic capital, and overemphasize the dominant language at the expense of students' native languages (Lo Bianco, 2017). This is not only ineffective in learning the new language (Cummins, 2000, 2011) but also may result in the loss of the learners' native languages (Lo Bianco, 2017).

The risk of losing native languages promotes a monolingual society in which neither other languages nor their speakers are respected. Lo Bianco (2010, p. 23), among others, writes about "subtractive diversity": a process in which the dominant language overtakes mother tongue and renders its use, prominence and importance in the individual linguistic repertoire, eventually wiping out smaller languages in societies. Concerns about subtractive diversity often point to the distinction of indigenous languages, such as many indigenous languages in Australia (Zuckermann, Shakuto-Neoh \& Matteo, 2014) and Sami languages in Finland (Keskitalo et al., 2014). However, less attention is given to the fact that insensitive methods of teaching the dominant language may also subtract newly increased diversity (Lo Bianco, 2010). As Finnish linguist Tove Skutnabb-Kangas (2000, also in this journal in 2013) argues in her writing about "linguistic genocide", this process kills not only languages but parts of their speakers, too. Similarly, Williams (1992) argues that insensitive language teaching processes which fail to acknowledge students' backgrounds can "alienate [speakers of other languages] from their past, their culture, their family and even their identity" (p. $4)$.

This danger links to the idea that the purpose of EALD/F2 
education is primarily to prepare newly arrived students to live in a new society; that is, to adapt in one way or another. As EALD/ F2 teachers help students to internalise the new society's norms and values, they may simultaneously imply that those values and norms are fixed and superior to those that the students may be more familiar with. This view is aligned with a view of one-way adaptation: that society is static and that only new-comers must adapt. While noting the dangers of this, we also acknowledge that teaching students about their new home societies is important. However, this should be done by acknowledging that a teacher's interpretation of societal norms and values is one among many and that in multicultural societies, all members need to adapt. From a praxis-perspective, teachers should acknowledge that teaching about the values and norms of a society "makes history" because the learners may adopt some of those values into their lives. However, at the same time, the students will enter society with their own ways of living, values and norms and thus, they also "make history" by renewing it.

Finally, teachers, considering time for the "recovery" of newly arrived students before they commence "real learning", may participate in implicit victimising of their students. Teachers might work as ethically and morally as they can with the knowledge available to them, but more experience and new evidence might show them that their means do not meet the aims. There is strong research evidence that common assumptions about refugee students should be challenged (Boyden 2013; Clark-Kazak, 2012; Kaukko \& Wilkinson, 2018; Orgocka, 2012, Vervliet et al., 2015), and that learner-centred approaches work especially with very diverse groups of learners (Dryden-Peterson, 2016; Pastoor, 2015; Pugh et al., 2012), but the "bigotry of low expectations" (Dumenden, 2014) continue to add to the challenges faced by EALD/F2 students in Finland (Alisaari, Attwood, Commins, Vigren, \& Acquah, 2018, September) and elsewhere (Roy \& Roxas, 2011). Even if teachers would want to avoid assumptions and place students' resources and needs at the centre in order to provide them with optimal learning opportunities, the problem teachers face is lack of professional development which would equip them to recognise the needs and resources of students from backgrounds that teachers are not familiar with (Pastoor, 2016). Teachers seem to have good intentions towards their students, but many lack knowledge about how to support students' needs beyond language 
(Alisaari et al., in press). Although Australia has a long history with diverse groups of students in schools, initial findings from ongoing research (Noble, 2017, November) shows that Australian mainstream teachers also have a limited understanding of their students' cultural backgrounds, and how to build on them in education practice.

It has also been argued that because the Finnish educational system has such a long history of teaching only the "mainstream" Finnish students, much of the multicultural rhetoric is superficial (Zilliacus, Holm \& Sahlström, 2017). Peguero and Bondy (2011), Suarez-Orozco et al. (2009) and Souto (2011), among others, argue that it is common that relationships in classrooms are highly structured according to the perceived value of linguistic, ethnic and national groups. It is also common that language teachers are unaware of these relations of power.

The above mentioned assumptions related to languages or groups of people are not limited to teaching and learning the dominant language, but are rather fixed within deeply rooted structures and ideologies in society. There are many examples of well-meaning individuals who are unaware of how to interact with migrant people, and of more systemic examples of unequal treatment for groups identified by language or background in all societies, all of which constrain a multicultural "world worth living in". Praxis-oriented teachers keep learning and reflecting on what they think makes sense in their work, problematizing assumptions about what their students need most in that particular moment, and what the desirable outcome would be.

Above we have listed just a few of the many examples of how educational practices with good intentions may produce unintended effects on newly arrived migrant students. We argue, in line with Williams (1992), that if care is not taken, "teachers in TESOL programs [and we would add, all programs of other languages] can easily become the de facto agents of assimilation" (p. 5). In teaching EALD/F2, just as much as any teaching, it is dangerous to think that "because our intentions are honourable we don't have any responsibility for unintended consequences of our actions" (p. 5).

Now we briefly move into describing Australia and Finland as contexts for educational praxis in EALD/F2 teaching. We acknowledge that the demographic situations of these two countries are different, and thus, we are cautious not to make any direct comparisons. 


\section{Australia and Finland}

As one of the most culturally diverse societies in the world, 26 percent of the Australian population is born overseas (Australian Human Rights Commission, 2018), whereas Finland has a shorter history of migration and is ethnically a much less diverse society (Korkiasaari, 2017). In 2014, less than six percent of people in Finland were born outside of Finland, and about the same proportion spoke a language other than Finnish or Swedish (Finland's other official language, spoken by approximately five percent of the population in Finland as their first language) (Family Federation of Finland, 2017).

Another significant difference in relation to the topic of this article is language. The language of Australia is English, quite often seen as the global Lingua Franca, although problematically so because of its elitist nature and its roots in imperialism and colonisation (Lo Bianco, 2010; Phillipson, 2013). The language of Finland, Finnish, is far from a Lingua Franca; it is spoken only in Finland, and it is not even related to the languages of the neighbouring countries - Sweden, Norway or Russia. (However, it is related to another small language of Estonia). Consequently, there is hardly a risk of Finnish displacing other languages even in Finland. In fact, policies are put in place to protect the Finnish language in Finnish education and academia, because of the threat of being dominated by English (Kristinsson \& HilmarssonDunn, 2012).

The majority of Finns and Australians see the "world worth living in" as multicultural. The most recent Scanlon-Monash Index (SMI) of Social Cohesion 2007-2016 (Markus, 2017) explored Australian attitudes to social cohesion, immigration and population issues in domains such as sense of belonging, sense of worth, sense of social justice, participation and acceptance of cultural diversity. The study showed that Australians have generally positive attitudes towards cultural diversity. 83 per cent agreed that multiculturalism has been good for Australia and 74 per cent felt that they got on well with people from different cultural and ethnic backgrounds in their local area. The high levels of social cohesion in Australia have been consistent since the annual survey began in 2007 (Pakulski, Markowski \& Markus, 2014), although recently, social divisions among some ethnic groups are being exacerbated (Blair, Dunn, Kamp \& Alam, 2017).

In Finland, attitudes towards immigration have improved rapidly in the last three decades. In 1997, as many as 78 per cent 
of Finns identified themselves as racist at least to a certain extent (Scheepers, 2002), but the most recent European Commission Public Opinion Survey (2017) showed that in autumn 2015, 77 per cent of Finns expressed positive feelings about the immigration of people from other EU Member States. The attitudes towards nonEU immigrants were slightly more critical, but they are more positive as compared to other European countries (European Commission, 2017).

In the light of these figures, it seems plausible that both countries are committed to supporting social cohesion, inclusion, or whichever of the problematic terms we want to use to define a "society [that] works towards the well-being of all its members, fights exclusion and marginalisation, creates a sense of belonging, promotes trust, and offers its members the opportunity of upward mobility" (Kincaid, 2011, p. 17). This commitment is evident in official educational and societal priorities. A "fairer Australia" (Department of Prime Minister and Cabinet, 2011) requires acknowledgement and support for linguistic diversity, which should provide the foundation for a more just society (Neilsen, Weinmann \& Arber, 2017, p. 2). In line with this priority, and unlike some other English-speaking countries (USA, UK), it is argued that learning the language of Australia is a right (rather than a responsibility) of newly arrived migrants (Lo Bianco, 2017). Similarly, the Finnish Government Integration Programme (2016, p. 10) declares that "It is the duty of the authorities to constantly assess and develop our service system so that it optimally enables those with different linguistic and cultural backgrounds to have equal opportunities in Finnish society".

While these figures and priorities paint a picture of a harmonious world worth living in, they might not fully reflect the realities of EALD/F2 classrooms. Schools are accountable for their outcomes, which do not "measure" social cohesion or inclusion. In the last part of the article, we draw on our interview data and country specific resources and policies, and briefly discuss the practice of EALD/F2 teaching.

\section{EALD/F2 in practice}

Students who arrive in Australia and speak a language other than English and who hold a visa that entitles them to enrol in a government school receive government funded intensive EALD training before entering a mainstream school. The Australian Curriculum for mainstream teaching acknowledges the need for 
differentiated support for diverse students, stating that EAL students "require additional time and support, along with informed teaching that explicitly addresses their language needs, and assessments that take into account their developing language proficiency" (ACARA, 2012, p. 1). Curriculum, pedagogic and assessment materials for both intensive language teaching (such as language schools) and mainstream EALD teaching is provided. These include, for example, The EAL Handbook (2017) and English as an Additional Language or Dialect: Teacher Resource (ACARA, 2012) and EAL/D Elaborations of the Australian Professional Standards for Teachers (ACTA, 2015). While many resources offer quite practical tools for planning and implementing lessons for learners with different levels of English, some consideration is also given to the ideals guiding EALD education. For instance, according to the EAL Handbook, the optimal conditions for learning English in Australia require that teachers know and acknowledge their students' diverse learning histories and achievements in their first language and any additional languages (Department of Education and Training, 2017, pp. 6-8).

Finnish public education is based on the ideal of providing the same educational opportunities for all, seeing education as the common good and a tool to create solidarity (Niemi, Toom \& Kallioniemi, 2012). In line with this, the support offered to newly arrived students in Finland is flexible and needs-based. The aim is to provide enough extra language support for students so that they will have the same educational opportunities as those who speak Finnish or Swedish as their first language, and that they will be able to participate fully in the mainstream education. As a guideline, newly arrived students are entitled to receive approximately 900 hours (primary level) to 1000 hours (secondary) of intensive language teaching before their transition to a mainstream classroom. This can be arranged in specific F2 groups, or inclusively, in mainstream classrooms. The Finnish Core Curriculum (Finnish National Agency for Education, 2014) requires all teachers to be language teachers and educate students in a culturally sustained manner. Teachers are expected to support not only Finnish but also multilingualism, taking into consideration the linguistic and cultural capacities which students bring to their learning. Overall, in addition to providing sufficient language skills to study in a mainstream classroom, F2 teaching aims to provide tools for inclusion to the new society (Finnish National Agency for Education, 2014, p. 121). 
In our research projects, we interviewed teachers who work in preparatory language classrooms for newly arrived students in both Finland and Australia, and in multicultural mainstream classrooms in both countries. The Finnish participants were enrolled in an in-service program targeted at teachers moving from mainstream classrooms into preparatory education. The Australian teachers were interviewed as part of a larger research study: Education through the Eyes of a Refugee Child (Kaukko \& Wilkinson, 2018). In both projects, one of the aims was to find out how teachers develop their professional praxis to work with newly arrived migrant students.

All teachers discussed the EALD/F2 resources which guide their work, and the different ways in which these resources refer to inclusion or social cohesion. The work of these teachers beyond language teaching was discussed in many interviews. The participants in both countries confirmed that values, "Finnish" and "Australian", are mentioned but not specified in their respective curricula related to EALD/F2 teaching, so it was left up to the teachers as to how they interpreted them. Most teachers in both countries acknowledged the problematic assumptions in discussions about values or norms as being fixed and stable, especially when working with newly arrived migrants, and instead of imposing values and norms, they tried to encourage open dialogue in their classrooms (within the limitations of the language). Likewise, teachers in both countries also confirmed that talking about the value of diversity, not only for the students, but for the whole school and the wider society, is part of their work. While they felt this work was important, they found when doing it, they were often a "buffer" between the students and the wider society and that this was draining.

The teachers from both countries repeatedly mentioned that they have high expectations for their learners, regardless of their background. The trouble-centred view of refugee learners, which is common in much research into refugee education (for example, Graham et al., 2016), was not prominent in the our interviews. The teachers of Australian and Finnish students acknowledged the hardships of students coming from crisis areas with disrupted educational backgrounds, but rather than accepting this as limiting for the students, they talked about ways to work around the challenges, while maintaining their high standards. The way the teachers talked in our interviews is in contrast with previous, large scale research in Finland (Alisaari et al., 2018, September), 
which showed that many mainstream teachers had significantly lower expectations for their F2 students. This difference in research findings may partially be explained by the differences of the participant groups: mainstream teachers versus EALD/F2 teachers. In line with Kubota (2002, p. 86), we believe working in EALD/F2 attracts certain kinds of teachers; those who are willing to work with students from different cultures. Moreover, the teachers who knew our topic and volunteered to be interviewed were probably already interested in ethics and praxis. However, in our view, these responses illustrate the ethical praxis in EALD/F2 education.

Teachers in both countries, but more so in Finland, talked about their possibilities of working ethically and reflectively in their own contexts. Compared to the curricula of Australian EALD teaching, Finnish Core Curriculum is much more flexible and open ended, allowing F2 teachers to plan the practical implementation they consider appropriate for their students. Another significant difference from a praxis point of view is how students' home or native languages can be recognised after their transition. Finnish schools are recommended to organise native language teaching for students, and while it is not mandatory, it is commonly arranged. Currently, over 50 native languages are taught in Finnish schools during school hours (Finnish Ministry of Education and Culture, 2017). While schools aim to find qualified teachers for all the language groups, it is rarely possible. Teaching is often arranged by native speakers; parents or some other members of a community. This was praised by the Finnish F2 teachers in our study for being both effective in supporting learning beyond the learners' first language, but also in involving families and showing respect for students' cultures and communities. Australian primary schools teach foreign languages, but rarely offer home language education for migrant students. Instead, community language schools in Australia arrange native language education outside of school hours, and these classes are often taught by volunteer teachers (Gindidis, 2013).

Supporting native languages is common sense in multilingual contexts of education and it was acknowledged by EALD/F2 teachers in both countries. On the other hand, research by Alisaari and colleagues (2018, September) and Noble (2017, November) show another picture of Finnish and Australian schools. Many mainstream teachers in both countries have inadequate knowledge and (perhaps consequently), may even have negative attitudes 
towards students' use of their native languages, and multilingualism in general (Alisaari et al., 2018, September; Noble, 2017, November). And it is these negative attitudes that matter more because they have an important impact on how the teachers interpret the curriculum and what takes place in the classroom.

\section{Discussion}

Praxis approach "takes a view about how people should live in the world, and about the kind of world they should aim to establish" (Kemmis et al., 2014, p. 27). For the individual learner, educational praxis is about the formation of persons who can live a good life; who are able to communicate and who feel accepted in their new home countries. For the social world, it concerns the formation of communities and societies which enable a good life for all. The world worth living in in both Finland and Australia appears to be multilingual and multicultural in its aims, but working with the ideals on the one side, and the country-specific policies on the other side, ethical praxis in EALD/F2 education is challenging.

The desired outcome in both EALD and F2 teaching is students' fast and smooth transition into mainstream education. The world worth living in can be seen as one where newly arrived migrant children and youth are educated to exit EALD/F2 classes quickly, and find their ways to contribute. As students transit into mainstream education, their use of native languages may or may not be supported, and their different capitals and skillsets may or may not be appreciated, although the aim is a multilingual and multicultural society in both countries. In both Australia and Finland, the extent to which EALD and F2 education is ethical praxis depends to a large extent on the teacher. A praxis oriented teacher, considering her work ethically, autonomously, reflectively and rationally, would most likely reach a conclusion that teaching practices that promote one-way assimilation do not promote a good life for individuals (who would lose parts of their identity) nor benefit humankind (which would lose opportunities for greater diversity).

Praxis with newly arrived migrant children is "historymaking action": it informs the field as much as it is informed by what happens in classroom and in the world, including the changing social-political climate of its context and education in general. Therefore, definitions of "best practice" in language teaching, or any other education, are fluid; they are "best" only until more suitable ones are discovered. That is why we do not aim 
to draw conclusions, or even present a plan of action or list recommendations for research and practice with newly arrived students. Instead, we aim to offer some conceptual tools for considering educational praxis with newly arrived migrant children. By doing this, we invite EALD/F2 teachers to critically and continuously consider their work, and the world they educate our children for. These ethical questions are as timely today as they have always been.

\section{Acknowledgement}

The authors would like to thank Alex Kostogriz, Jenni Alisaari and the anyonymous reviewers for their valuable comments on this article.

\section{References}

Australian Council of TESOL Associations (ACTA). (2015). EAL/D elaborations of the Australian Professional standards for teachers for use when working with learners of English as an additional language or dialect $(E A L / D)$. Retrieved from http://www.tesol.org.au/files/files/531_60238_EALD_ elaborations-Full_Version_Complete.pdf

Australian Human Rights Commission (2018). Face the facts. Retrieved from https://www.humanrights.gov.au/face-factscultural-diversity

ACARA. (2014). English as an additional language or dialect teacher resource EAL/D learning progression: Foundation to year 10; Australian Curriculum, Assessment and Reporting Authority (ACARA) 2013.

Alisaari, J., Heikkola, L. M. Commins, N. \& Acquah, E. (in press). Monolingual ideologies confronting multilingual realities. Teaching and Teacher Education.

Alisaari, J., Attwood, E., Commins, N., Vigren, H., \& Acquah, E. (2018, September). Schooling expectations for learners from migrant background: Contrasting views of Finnish teachers and immigrant parents. Presentation at the European Conference on Educational Research (ECER), Bolzano, Italy.

Australian Curriculum and Assessing and Reporting Authority. (2012). Diversity of learners. Retrieved from http://docs. acara.edu.au/resources/Information_Sheet_Diversity_of_ learners.pdf

Blair, K., Dunn, K., Kamp, A., \& Alam, O. (2017). Challenging racism project: 2015-16 national survey. National Survey 
Report. Penrith, N.S.W: Western Sydney University. doi: $10.4225 / 35 / 58 \mathrm{cb} 62 \mathrm{~d} 270392$

Boyden, J. (2013). "We're not going to suffer like this in the mud": Educational aspirations, social mobility and independent child migration among populations living in poverty. Compare: A Journal of Comparative Education, 43(5), 580-600. doi:10.1080/03057925.2013.821317

Carr, W., \& Kemmis, S. (1986). Becoming critical. London: Falmer. Clark-Kazak, C. (2012). Challenging some assumptions about 'refugee youth'. Forced Migration Review, (40), 13-14.

Correa-Velez, I., Gifford, S. M., \& Barnett, A. G. (2010). Longing to belong: Social inclusion and wellbeing among youth with refugee backgrounds in the first three years in Melbourne, Australia. Social Science E Medicine, 71(8), 1399-1408. doi:10.1016/j.socscimed.2010.07.018

Crookes, G. (2009). Values, philosophies, and beliefs in TESOL: Making a statement. Cambridge: Cambridge University Press.

Cummins, J. (2000). Language, power and pedagogy. Clevedon: Multilingual Matters.

Cummins, J. (2011). Putting the evidence back into evidence-based policies for underachieving students. Language Policy Division, Directorate of Education and Languages, Council of Europe. Retrieved from https://www.coe.int/t/dg4/linguistic/

Department of Prime Minister and Cabinet. (2011). Foundations for a stronger, fairer Australia. Social Inclusion Unit. Canberra, Australia.

Doecke, B., Kostogriz, A., \& Illesca, B. (2010). Seeing "things" differently: Recognition, ethics, praxis. English Teaching: Practice and Critique, 9(2), 81-98. Retrieved from https:// edlinked.soe.waikato.ac.nz/research/files/etpc/ files/2010v9n2dial1.pdf

Dryden-Peterson, S. (2016). Refugee education. Educational Researcher, 45(9), 473-482. doi:10.3102/0013189X16683398 Dufon, M. (1993). Ethics in TESOL research. TESOL Quarterly, 27(1), 157-160. doi:10.2307/3586970

Dumenden, I. (2014). The soft bigotry of low expectations: The refugee student and mainstream schooling. British Journal of Sociology of Education, 35(3), 484-486. doi:10.1080/0142569 2.2014.904144

Department of Education and Teaching. (2017). The EAL Handbook. Advice to schools on programs for supporting students learning English as an additional language. Department of Education 
and Training.

European Commission. (2017). Standard public opinion. Retrieved from http://ec.europa.eu/commfrontoffice/ publicopinion/index.cfm/Survey/getSurveyDetail/ instruments/STANDARD/surveyKy/2143

Family Federation of Finland. (2017). Maahamuuttajien määrä Suomessa. Retrieved from http://www.vaestoliitto.fi/tieto_ ja_tutkimus/vaestontutkimuslaitos/tilastoja/ maahanmuuttajat/maahanmuuttajien-maara/

Finnish Government. (2016). Government integration programme for 2016-2019 and government resolution on a government integration programme. Publications of the Ministry of Economic Affairs and Employment Ministry, 47/2016, Retrieved from https://julkaisut.valtioneuvosto.fi/bitstream/ handle/10024/79156/TEMjul_47_2016_verkko. pdf?sequence $=1$

Finnish Ministry of Education and Culture. (2017). Maahanmuuttajien opetus. Ministry of Education.

Finnish National Agency for Education. (2014). Finnish National Core Curriculum for Basic Education Helsinki: Finnish National Agency for Education.

Freire, P. (1969/2000). Pedagogy of the oppressed (30th anniversary ed.). New York: Continuum.

Gindidis, M. (2013). Australian community languages teachers: A phenomenological study. Doctoral Dissertation, Monash University.

Graham, H., Minhas, R., \& Paxton, G. (2016). Learning problems in children of refugee background: A systematic review. Pediatrics, 137(6). doi:10.1542/peds.2015-3994

Groundwater-Smith, S., Mitchell, J., Mockler, J., Ponte, P. \& Rönnerman, K. (2013). Facilitating practitioner research: Developing transformational partnerships. Abingdon, Oxon; New York: Routledge.

Habermas, J. (1973). Theory and practice. Boston: Beacon.

Habermas, J. (1989). The theory of communicative action. Cambridge: Polity Press.

Habermas, J. (1984). The theory of communicative action: Lifeworld and system: A critique of functionalist reason (Vol. 2). Boston: Beacon.

hooks, b. (2007). Vapauttava kasvatus. Helsinki: Kansanvalistusseura. Kaukko, M., \& Wilkinson, J. (2018). Learning how to go on': Refugee students and informal learning practices. 
International Journal of Inclusive Education. doi: $10.1080 / 13603116.2018 .1514080$

Kemmis, S. (2009). Action research as a practice-based practice. Educational Action Research, 17(3), 463-474. doi:10.1080/09650790903093284

Kemmis, S., \& Smith, T. J. (2008). Enabling praxis: Challenges for education. Rotterdam, The Netherlands: Sense Publications.

Kemmis, S., Wilkinson, J., Edwards-Groves, C., Hardy, I., Grootenboer, P., \& Bristol, L. (2014). Changing practices, changing education. Singapore: Springer.

Keskitalo, P., Määttä, K., \& Uusiautti, S. (2014). "Language immersion tepee" as a facilitator of Sámi language learning. Journal of Language, Identity, and Education, 13(1), 70-79. doi $: 10.1080 / 15348458.2014 .864215$

Kincaid, K. (2011). Perspectives on global development 2012. Paris: OECD.

Korkiasaari, J. (2017). Maahanmuutto ja ulkomaalaiset Suomessa "Ensimmäinen suomalainenkin oli ulkomaalainen"; Turku, Finland: Institute of Migration/Siirtolaisuusinstituutti.

Kristinsson, A. P., \& Hilmarsson-Dunn, A. (2012). Unequal language rights in the Nordic language community. Language Problems and Language Planning, 36(3), 222-236. doi:10.1075/ lplp.36.3.02kri

Kubota, R. (2002). The author responds: (Un) Raveling racism in a nice field like TESOL. TESOL Quarterly, 36, 84-92. doi: $10.2307 / 3588363$

Lo Bianco, J. (2017 September). Language, education and social cohesion. Paper presented at the Language and Literacy Research Hub seminar: What are the connections between education and social cohesion? Educational, linguistic and psychological perspectives. At Melbourne Graduate School of Education, Parkville.

Lo Bianco, J. (2010). Some ideas about multilingualism and national identity. TESOL in Context, 20(1), 22-36.

Markus, A. (2017, September). Mapping social cohesion. Paper presented at the Language and Literacy Research Hub seminar: What are the connections between education and social cohesion? Educational, linguistic and psychological perspectives. At Melbourne Graduate School of Education, Parkville.

Marx, K., \& Engels, F. (1845/1998). The German ideology. Amherst, NY: Prometheus Books. 
Mattsson, M Johansson, I. \& Sandström, B. (2008). Examining praxis: Assessment and knowledge construction in teacher education. Rotterdam: Sense Publishers.

Neilsen, R., Weinmann, M., \& Arber, R. (2017). Australian TESOL contexts; a state of flux. TESOL in Context, 26(1), 2-6.

Niemi, H., Kallioniemi, A., \& Toom, A. (2012). Miracle of education: The principles and practices of teaching and learning in Finnish schools. Rotterdam; Boston: Sense.

Noble, G. (2017, November). Doing diversity differently: multicultural education for a culturally complex world, Keynote Presentation at the Australian Association for Research in Education-Conference, November 2017, Canberra, Australia.

Orgocka, A. (2012). Vulnerable yet agentic: Independent child migrants and opportunity structures. In A. Orgocka, \& C. Clark-Kazak (Eds.), Independent child migration - insights into agency, vulnerability and structure (pp. 1-13). San Francisco: Wiley Periodicals.

Pakulski, J., Markowski, S., \& Markus, A. (2014). Attitudes to immigration and cultural diversity in australia. Journal of Sociology, 50(1), 10-22. doi:10.1177/1440783314522188

Pastoor, L. (2015). The mediational role of schools in supporting psychosocial transitions among unaccompanied young refugees upon resettlement in Norway. International Journal of Educational Development, 41, 245-254. doi:https://doi. org/10.1016/j.ijedudev.2014.10.009

Pastoor, L. (2016). Rethinking refugee education: Principles, policies and practice from a European perspective. International Perspectives on Education and Society, 30, 107116. doi: 10.1108/S1479-367920160000030009

Peguero, A. A., \& Bondy, J. M. (2011). Immigration and students' relationship with teachers. Education and Urban Society, 43(2), 165-183. doi:10.1177/0013124510380233

Phillipson, R. (2013). TESOL expertise in the empire of English. TESOL in Context, 22(2), 5-16. Retrieved from http:// search.informit.com.au/fullText;res=AEIPT; $\mathrm{dn}=201406$

Ponte, P., \& Smit, B. H. J. (2013). Education for all as praxis: Consequences for the profession. Professional Development in Education, 39(4), 455-469. doi:10.1080/19415257.2013.796 296 
Pugh, K., Every, D., \& Hattam, R. (2012). Inclusive education for students with refugee experience: Whole school reform in a south Australian primary school. Australian Educational Researcher, 39(2), 125-141. doi:10.1007/s13384-011-0048-2

Roy, L., \& Roxas, K. (2011). Whose deficit is this anyhow? exploring counter-stories of Somali Bantu refugees' experiences in "doing school". Harvard Educational Review, 81(3), 521-541.

Scheepers, P., Gijsberts, M., \& Coenders, M. (2002). Ethnic exclusionism in European countries. public opposition to civil rights for legal migrants as a response to perceived ethnic threat. European Sociological Review, 18(1), 17-34. doi:10.1093/esr/18.1.17

Skutnabb-Kangas, T. (2000). Linguistic genocide in education, or worldwide diversity and human rights? Mahwah, N.J.: L. Erlbaum Associates.

Skutnabb-Kangas, T. (2013). Today's Indigenous education is a crime against humanity: Mother- tongue- based multilingual education as an alternative? TESOL in Context, 23(1), 82-124.

Souto, A.-M. (2011). Arkipäivän rasismi koulussa. Etnografinen tutkimus suomalais- ja maahanmuuttajanuorten ryhmäsuhteista. University of Eastern Finland.

Suarez-Orozco, C., Pimentel, A., \& Martin, M. (2009). The significance of relationships: Academic engagement and achievement among newcomer immigrant youth. Teachers College Record, 111(3), 712-749.

Usman, L. M. (2012). Communication disorders and the inclusion of newcomer African refugees in rural primary schools of British Columbia, Canada. International Journal of Progressive Education, 8(2), 102-120.

van Kan, C. A., Ponte, P., \& Verloop, N. (2013). How do teachers legitimize their classroom interactions in terms of educational values and ideals? Teachers and Teaching, 19(6), 610-633. doi :10.1080/13540602.2013.827452

Vervliet, M., Rousseau, C., Broekaert, E., \& Derluyn, I. (2015). Multilayered ethics in research involving unaccompanied refugee minors. Journal of Refugee Studies, 28(4), 468-485. doi:10.1093/jrs/feu039

Wilkinson, J. (2017). Reclaiming education in educational leadership. In P. Grootenboer, C. Edwards-Groves \& S. Choy (Eds.) Practice theory perspectives on pedagogy and education: 
Praxis, diversity and contestation (pp. 231-241). Singapore: Springer International.

Wilkinson, J., Bristol, L., \& Ponte, P. (2016). Professional development: Education for all as praxis. Abingdon: Routledge.

Williams, A. (1992). The ethics of TESOL. TESOL in Context, 2(2), $4-5$.

Zilliacus, H., Holm, G., \& Sahlström, F. (2017). Taking Steps towards Institutionalising Multicultural Education -The National Curriculum of Finland. Multicultural Education Review, 9(4), 231-248. doi: 10.1080/2005615X.2017.1383810 Zuckermann, G., Shakuto-Neoh, S., \& Matteo G. (2014). Native tongue title: Proposed compensation for the loss of Aboriginal languages. Australian Aboriginal Studies (AAS) 2014(1), 55-71.

Mervi Kaukko is a Finnish researcher and a teacher, currently based at Monash University, Australia. Mervi's current research has three primary areas: migration and refugee research, intercultural education and practice theories/praxis. For example, Mervi is interested in finding out what kind of educational arrangements enable refugee students' learning and school wellbeing in their new home countries.

mervi.kaukko@monash.edu

Jane Wilkinson is Associate Dean, Faculty of Education, Monash University. Jane researches educational leadership for social justice focusing on youth of refugee origin in schools and universities. Jane's latest book is Navigating complex spaces: Refugee background students transitioning into higher education (with Naidoo, Adoniou and Langat, Singapore: Springer, 2018).

jane.wilkinson@monash.edu 